\title{
Mecatrone, volume 2
}

Todos nós sabemos que muitos estudantes de engenharia não gostam de escrever, porém há algumas exceções (como eu) que curtem fazer isso, mas a falta de tempo para focar nessa atividade é um dos maiores problemas que nos faz desanimar. Aliás, a falta de tempo é o maior inimigo do politécnico... (não só do politécnico, mas arriscaria dizer de qualquer pessoa que vive no mundo globalizado de hoje).

Assumir o papel de editora-chefe da revista Mecatrone durante esse ano foi desafiador. Quis tocar esse projeto pois via que a revista estava estagnada e queria torná-la ativa de novo, com boa visibilidade. Aparentemente, a revista não oferecia nenhum desafio. Para ser sincera, imaginei que seria necessária apenas uma boa divulgação para que os alunos enviassem textos, mas não foi bem desse jeito. Era a primeira vez que acessava o Sistema Integrado de Bibliotecas USP - SIBiUSP e, por assim dizer, certas coisas nesse sistema não são tão intuitivas. Com isso, tive que aprender a usar o sistema desde o básico e, também, entender o passo a passo de uma publicação de texto. Também tive que enfrentar o já citado inimigo comum a todos para conseguir avançar com a revista: passei um bom tempo fazendo textos e cartazes para divulgação, atualizando os templates de Word e LaTex, arrumando a capa das edições, enviando para os avaliadores os artigos já submetidos e esperando que novos textos fossem enviados para serem publicados.

Finalmente, após um ano de trabalho e com o esforço de todos, foi lançado o segundo volume, juntamente com o concurso cultural para escolha de sua capa! Espero que a Mecatrone possa ajudá-lo na hora de fazer seus textos durante o curso de engenharia, e que a revista o motive a ler, documentar e publicar seus projetos. Agradeço a toda equipe que me ajudou durante esse tempo: ao Prof ${ }^{\circ}$ Celso Furukawa, por todas as reuniões realizadas e pela paciência em tirar todas as dúvidas que encontrei; à Maria de Fatima, da biblioteca, que sempre esteve à disposição para avaliar os artigos; ao André Serradas, do SIBiUSP, que deu o suporte necessário para entender melhor o sistema; aos amigos do PET Mecatrônica, que acompanharam todo o processo, divulgando e opinando sobre a revista, e aos antigos editores-chefe da Mecatrone (Andrei Saito Ramalho, Rodrigo Rejaili e Tito Martini), por terem iniciado o projeto e dado continuidade antes de eu assumir.

Desejo a todos uma boa leitura e que venham mais edições da revista Mecatrone!

Bruna Sayuri de Souza Suzuki cursa Engenharia Mecatrônica desde 2015 e, nesse mesmo ano, se tornou membro do PET Mecatrônica. Foi também editora-chefe da revista Mecatrone durante o ano de 2017. 
Vasculhando arquivos mais antigos da revista, encontrei o texto que está logo abaixo, parte da divulgação nos meios eletrônicos da Poli no início do projeto, em meados do início de 2015. É bem interessante, pois conta um pouco mais da história da revista. Espero que gostem.

\section{Estudantes da Poli criam revista eletrônica sobre Engenharia Mecatrônica}

Com espaço dedicado a artigos científicos e resenhas sobre soluções tecnológicas, alunos de graduação podem publicar suas ideias e trabalhos

Os estudantes do curso de graduação em Engenharia Mecatrônica da Escola Politécnica da USP desenvolveram uma revista eletrônica colaborativa de caráter científico, tecnológico e educacional, que aceita artigos que contemplem a área de Engenharia Mecatrônica e áreas relacionadas, a Mecatrone. 0 objetivo da publicação é fomentar a escrita e a leitura de artigos científicos por parte dos alunos de graduação e a colaboração entre eles.

A revista foi concebida e fundada em 2014, por alunos de Engenharia Mecatrônica da Poli, com o apoio do Prof. Celso Furukawa, do Departamento de Engenharia Mecatrônica e de Sistemas Mecânicos (PMR). Atualmente, é organizada pelo PET Automação e Sistemas e terá o lançamento de sua primeira edição no final de Setembro de 2015. Um dos idealizadores do projeto, o aluno Andrei Saito Ramalho conta que a equipe percebeu que, durante o curso, os alunos desenvolvem muitos projetos de extrema relevância e qualidade para disciplinas de graduação, que muitas vezes acabam perdidos. "Além do mais, não há fácil acesso entre os alunos de trabalhos de iniciações científicas já realizadas ou trabalhos de formatura. Assim, buscamos facilitar a divulgação dos trabalhos produzidos pelos alunos".

O professor da Poli-USP Celso Massatoshi Furukawa, que orienta o projeto, explica que uma revista estudantil promove a aproximação dos alunos com o mundo das publicações científicas, como autores e também como editores e revisores. "Assim, mais cedo eles poderão entender a importância do processo de revisão por pares para assegurar a qualidade do que é publicado, em contraponto à profusão de informação que se encontra publicada informalmente na rede."

Sob a orientação de professores, toda a equipe editorial da revista é composta por alunos, membros do PET Automação e Sistemas, que são responsáveis pela organização e manutenção da revista, desde aspectos técnicos, até a seleção e revisão de artigos. "Contamos ainda com a colaboração de bibliotecárias da Escola Politécnica para orientar os alunos a fazerem a pesquisa bibliográfica e a escreverem os artigos seguindo as normas para artigos científicos", conta Andrei.

O projeto recebe apoio da Diretoria da Escola Politécnica da USP e do Departamento de Engenharia Mecatrônica e Sistemas Mecânicos (PMR), através de seus professores e funcionários, da Divisão de Bibliotecas da Poli, pelo apoio das bibliotecárias, e do SIBi USP, por hospedar a revista Mecatrone no Portal de Revistas Eletrônicas da USP. 
Para atuar como autor, basta submeter um artigo no site da revista, e para atuar como um revisor, deve-se entrar em contato com a Equipe Editorial da revista. Atualmente, apenas membros do PET são editores da revista, mas a equipe tem a intenção de que o projeto cresça, e se expanda para receber participações de alunos outras universidades.

A revista pode ser acessada no link http://www.revistas.usp.br/mecatrone. 